\title{
TANGGUNG JAWAB SOSIAL PERUSAHAAN TERHADAP MADRASAH
}

\author{
Ahmad Juhaidi \\ Institut Agama Islam Negeri (IAIN) Antasari \\ Jl. A. Yani Km. 4,5 Banjarmasin Kalimantan Selatan, telp. 3253939 \\ Email: ahmad-juhaidi@yahoo.com.
}

\begin{abstract}
ABSTRAK
Tulisan ini bertujuan mengkaji alternatif sumber pembiayaan pendidikan di madrasah dengan mengggunakan program corporate social responsibility (CSR). Pendekatan yang digunakan adalah deskriptif analitis. Realisasi program CSR tersebut belum dirasakan nyata oleh pihak madrasah. Riset-riset terdahulu menunjukkan bahwa CSR cenderung lebih mementingkan pihak-pihak yang memiliki kekuatan untuk mempengaruhi perusahaan (shareholder) dan sangat sedikit memberikan manfaat bagi masyarakat serta lingkungan. Madrasah, sebagai salah satu lembaga pendidikan Islam di Indonesia kurang memiliki daya tawar yang kuat sehingga sering tidak mendapatkan alokasi pendanaan CSR. Madrasah dapat berpeluang mendapatkan dana CSR, dengan memperhatikan beberapa hal di antaranya; 1) lokasi madrasah terkena dampak langsung dari perusahaan, 2) melibatkan diri dalam program CSR dan 3) adanya akuntabilitas/jaminan transfaransi pengelolaan keuangan. Di pihak perusahaan, program CSR idealnya dijadikan sebagai trade mark, sebagai wujud tanggung jawab sosial perusahaan terhadap kepentingan masyarakat, khususnya pendidikan madrasah yang rata-rata milik masyarakat namun minim dari segi pendanaan.
\end{abstract}

Kata kunci: Tanggung jawab Sosial, Perusahaan, Madrasah

\section{ABSTRACT}

This paper aims to assess alternative sources of education funding in madrasab through corporate social responsibility program (CSR). The approach used is descriptive analytic. The realization of CSR program is not perceived real yet by the madrasah. Previous research indicates that CSR tends to be more concerned with those who have power to influence the company (shareholders) and provides very little benefit to society and the environment. Madrasah, as one of the Islamic schools in Inodnesia, Has no strong bargaining power which results in receiving no fund allocation from CSR. Madrasab is potential to get this funding by considering the following aspects: 1) the location of madrasah gets direct impacts of the company, 2) the madrasah is participated in CSR program, 3) the madrasah has performed accountability/transparency security regarding financial management. In the company, CSR programs should ideally be used as a trade mark, as a form of corporate social responsibility to the public interest, particularly to the education in madrasab which commonly belongs to the public, but has minimum funding.

Keywords: Social Responsibility, Corporate, Madrasah 


\section{PENDAHULUAN}

Kajian ini difokuskan pada upaya mencari peluang pembiayaan pendidikan yang bersumber dari program CSR perusahaan dalam rangka meningkatkan kualitas madrasah. Program CSR sebagai mitra kerja pemerintah kabupaten, dalam perencanaannya, cenderung tidak memperhatikan madrasah yang secara struktural bukan merupakan bagian dari (Kementerian Pendidikan dan Kebudayaan RI) pemerintah kabupaten. Selain itu, alokasi dana program CSR tidak didistribusikan langsung kepada proses belajar mengajar di madrasah (Juhaidi, 2012).

Rendahnya perhatian perusahaan tambang terhadap pembiayaan madrasah di daerah terdampak tersebut tidak sejalan dengan hakikat CSR yang merupakan bentuk tanggung jawab perusahaan atas dampak operasional perusahaan. Blowfield and Frynas (2005) menjelaskan secara rinci tanggung jawab perusahaan melalui program CSR atas dampak operasional perusahaan sebagai berikut:

(a) that companies have a responsibility for their impact on society and the natural environment, sometimes beyond that of legal compliance and the liability of individuals; (b) that companies have a responsibility for the behaviour of others with whom they do business (e.g., within supply chains); and (c) that business needs to manage its relationship with wider society, whether for reasons of commercial viability or to add value to society (Frynas, 2009: 6)

Penjelasan Frynas tersebut menunjukkan CSR merupakan bentuk tanggung jawab perusahaan atas dampak usaha mereka terhadap masyarakat dan lingkungan. CSR juga mencerminkan sebuah tanggung jawab perusahaan kepada pihak rekan bisnis mereka. Di sisi lain, CSR dapat pula dimaknai sebagai sebuah kebutuhan perusahaan untuk membangun hubungan dengan masyarakat yang lebih luas, untuk komersial atau untuk menambah nilai bagi masyarakat. CSR merupakan bentuk dari etika dan moral perusahaan (Frynas, 2009: 5).

\section{PEMBAHASAN}

\section{Beberapa Laporan Hasil Riset tentang CSR}

Dalam proses pendidikan dana menjadi salah satu input penting bagi peningkatan kualitas pendidikan. Teori hubungan biaya dengan output pendidikan dikemukakan oleh John, Morphet dan Kern (1983). Dua masalah mendasar hubungan antara biaya dan output pendidikan adalah apa target mutu yang akan dicapai melalui pendidikan dan bagaimana melaksanakannya, serta berapa biaya program pendidikan yang dibutuhkan dan bagaimana pendanaan program pendidikan tersebut. Mereka mengemukakan bahwa biaya dengan kuantitas pendidikan juga memiliki keterkaitan yang erat. Dalam sistem sekolah, peningkatan enrollment $10 \%$ akan meningkatkan biaya mendekati proporsi yang sama serta meningkatkan kualitas pendidikan sebagai konsekuensi biaya. 
John, Morphet dan Kern (1983) juga mengungkapkan bahwa biaya dapat mempengaruhi kualitas pendidikan. Akan tetapi, menurut mereka, antara biaya dan kualitas boleh jadi tidak ada keterkaitan secara signifikan karena: 1) pada sekolah-sekolah kecil, biaya per siswa cenderung besar daripada sekolah-sekolah besar. Akan tetapi, nilai sekolah kecil lebih rendah; 2) pada beberapa sekolah, rendahnya kualitas pendidikan lebih disebabkan oleh ketidaklayakan kepemimpinan dan administrasi; 3) kebijakan negara atau dewan tidak sesuai dengan zaman dan tidak mendukung kualitas layanan pendidikan; dan 4) pada banyak negara bagian dan sistem sekolah banyak ditemukan peningkatan kualitas pendidikan tanpa tambahan biaya.

Hasil penelitian lain menyebutkan bahwa peningkatan pengeluaran biaya berhubungan secara signifikan dengan meningkatnya prestasi (Greenwald., Hedges, \& Laine, 1996). Wenglinsky (1997) menegaskan bahwa terdapat hubungan yang sangat kuat antara uang dan prestasi. Misalnya, setiap USD 1 per siswa yang digunakan untuk pembelajaran berhubungan dengan meningkatnya 1 poin nilai mata pelajaran matematika. Penelitian Molly (2011: 357) yang dilakukan di Vermont menyimpulkan bahwa peningkatan pengeluaran biaya berdampak pada hasil kelulusan tes matematika. Menurutnya, 10\% peningkatan pengeluaran uang akan meningkatkan nilai kelulusan matematika sekitar 2 sampai 6 poin. Dia mengakui bahwa peningkatan hasil juga terjadi pada mata pelajaran lain tetapi peningkatan paling besar ditemukan pada pelajaran matematika.

Riset yang dilakukan Robert C. Dolan dan Robert M. Schmidt menyimpulkan bahwa expenditure effects on achievement may be stronger at the primary school level (Dolan \& Schmidt, 2002). Akan tetapi, pengeluaran sekolah tersebut menyangkut untuk apa alokasi pengeluaran tersebut, bukan berapa pengeluaran seluruhnya. Levavic (2007: 396) menjelaskan bahwa biaya merupakan salah satu komponen yang menentukan output lulusan sekolah. Dia menjelaskan bahwa output lulusan sekolah ditentukan oleh kombinasi dan interaksi beberapa faktor yaitu kontekstual, input dan variabel proses. Menurutnya, faktor kontekstual (misalnya tipe sekolah, kepemerintahan, masyarakat lokal dan komposisi sosial) tidak secara langsung di bawah kontrol sekolah. Input, dalam versi Levavic ini, dibagi menjadi input siswa dan input sumber daya. Input siswa, tulis Levavic, lebih terkait dengan karakteristik siswa yang mempengaruhi hasil belajarnya seperti umur, etnis, gender dan latar belakang keluarga.

Input sumber daya merupakan input yang diperoleh dengan membelanjakan sejumlah uang yaitu total pendapatan sekolah dan pengeluaran per siswa dalam sebuah periode waktu dan alokasi pengeluaran (monetary input): guru, staf, sumber pembelajaran dan pemeliharaan sarana sekolah. Selain monetary input tersebut dikenal juga real input yang diukur dengan kuantitas fisik yaitu rasio guru siswa, stok sumber belajar, fasilitas dan ruang. Levavic mengakui bahwa proses pembelajaran di sekolah bisa dilaksanakan dengan resources input dan terbatas dengan kekurangan resources input. 
Penelitian Elliott (Ross, et.all. 2007: 481) membuktikan bahwa ada hubungan antara biaya dengan hasil pembelajaran. Dia menyimpulkan bahwa lebih tinggi pengeluaran per murid di sebuah distrik, lebih tinggi pula nilai tingkat keefektivan pengajaran. Peralatan kelas yang lebih baik akan berakibat pada tingginya keefektivan pembelajaran dan peralatan kelas yang lebih baik akan berakibat pada tingginya prestasi belajar khususnya di bidang matematika dan sains. Studi Elliot tersebut menjadi argumen utama dikembangkannya teori keefektivan pembelajaran dari sumber pengeluaran. Pengeluaran per siswa akan meningkatkan prestasi siswa jika biaya/pengeluaran tersebut digunakan untuk membayar dan melatih guru yang berkualitas dalam metode pembelajaran yang efektif.

Penelitian yang lebih fokus tentang biaya apa saja yang dapat mempengaruhi nilai siswa dilakukan oleh Normore dan Ilon (2006). Penelitian yang dilakukan di Florida tersebut menyimpulkan bahwa biaya yang dikeluarkan untuk mereduksi jumlah siswa per kelas berpengaruh terhadap peningkatan prestasi belajar siswa. Biaya yang dikeluarkan untuk meningkatkan rasio staf administrasi dan meningkatkan kualitas guru dengan berbagai kegiatan pelatihan dan workshop akan berpengaruh positif terhadap hasil belajar siswa.

Penelitian tentang hubungan biaya dengan hasil belajar siswa dilakukan pula di Inggris. Holmlund, McNally dan Viarengo (2010) mengungkapkan bahwa di Inggris, pengeluaran untuk sekolah telah ditingkatkan sekitar $40 \%$ sejak tahun 2000. Mereka menemukan bahwa peningkatan pengeluaran pemerintah untuk sekolah secara konsisten berdampak positif terhadap hasil pembelajaran pada akhir sekolah dasar. Dia menekankan bahwa investasi untuk pendidikan tersebut harus dilakukan dengan keefektivan penggunaan biaya (cost effective).

Lebih rinci lagi, Wolf (Nishimuko, 2007) menjelaskan tentang hubungan antara biaya dan kualitas pendidikan. Menurutnya, salah satu komponen sebuah pendidikan berkualitas adalah kecukupan biaya dan sumber daya material. Selain biaya, lanjut Wolf, yang menjadi komponen dalam pendidikan berkualitas adalah ketepatan media pembelajaran, isi kurikulum yang tepat secara kultural dan metode mengajar yang profesional. Pada umumnya, para ahli sepakat bahwa biaya merupakan faktor yang sangat berpengaruh terhadap kualitas pendidikan.

Sebagai bagian dari masyarakat, para pengusaha merupakan sumber potensial bagi pembiayaan pendidikan. Bantuan dari perusahaan ini adalah input komplementer bagi proses pendidikan. Pada daerah industri, partisipasi perusahaan menjadi sangat penting bagi kemajuan pendidikan. Undang-Undang Nomor 40 Tahun 2007 tentang Perseroan Terbatas pada Pasal 74 menyebutkan bahwa perusahaan yang menjalankan kegiatan usahanya di bidang dan/atau berkaitan dengan sumber daya alam wajib melaksanakan tanggung jawab sosial dan lingkungan. Salah satu tanggung jawab sosial tersebut termanifestasi dalam pengembangan pendidikan di sekitar wilayah perusahaan. Pada pasal 1 ayat 3 dijelaskan bahwa tanggung jawab sosial dan lingkungan adalah komitmen perseroan untuk berperan serta dalam pembangunan ekonomi berkelanjutan 
guna meningkatkan kualitas kehidupan dan lingkungan yang bermanfaat, bagi perseroan sendiri, komunitas setempat, maupun masyarakat pada umumnya. Hal itu juga ditegaskan dalam UU Nomor 4 Tahun 2009 tentang Pertambangan Mineral dan Batu Bara pasal 95 ayat (d) yang mewajibkan perusahaan pertambangan untuk melaksanakan pengembangan dan pemberdayaan masyarakat setempat. Hal itu kemudian dipertegas lagi oleh PP Nomor 23 Tahun 2010 tentang pelaksanaan kegiatan usaha pertambangan mineral dan batu bara. Pada pasal 106 ayat (4) disebutkan pula bahwa prioritas program pengembangan dan pemberdayaan masyarakat tersebut adalah masyarakat yang terkena dampak langsung akibat aktivitas pertambangan.

Meskipun regulasi menuntut perusahaan agar melaksanakan program CSR, CSR harus dipandang sebagai tanggungjawab yang melintas batas peraturan. Frynas (2009: 6) menegaskan bahwa komitmen tidak hanya sebatas pemenuhan regulasi, tetapi juga sebagai komitmen untuk berkontribusi dalam pembangunan berkelanjutan. Di samping itu, pelaksanaan CSR memiliki keterkaitan dengan semakin baiknya kinerja perusahaan. Dengan kata lain, pelaksanaan CSR akan menjadi salah satu faktor penentu meningkatnya keuntungan perusahaan. Laporan Dow Jones menyebutkan bahwa nilai saham akan bergerak positif pada perusahaan-perusahaan yang mengimplementasikan CSR dalam aktivitas usaha mereka (Azheri, 2011: 120). Program CSR perusahaan akan membuka peluang terhadap pasar baru, keuntungan kompetitif dan kepuasan pelanggan (Buhrn dan Grafstrom, 2007: 27).

Hal itu dijelaskan oleh Elkington (1997) yang mengembangkan konsep triple bottom line yaitu economic prosperity, environmental quality dan social justice. Melalui konsep ini Elkington mengemukakan bahwa perusahaan yang ingin terus menjalankan usahanya harus memperhatikan 3P yaitu profit, people dan plannet. Perusahaan selain untuk meraih keuntungan (profit), mereka juga harus mengambil bagian dalam peningkatan kesejahteraan masyarakat (people) dan berpartisipasi dalam pelestarian lingkungan (planet). Dalam tataran praktis, konsep yang menjadi rujukan dalam pelaksanaan CSR tersebut, mendorong perusahaan untuk secara serius melaksanakan program yang benar-benar bermanfaat dan dinikmati masyarakat.

Tanggung jawab sosial perusahaan atau yang dikenal dengan corporate social responsibility merupakan bentuk tanggung jawab atas dampak operasional perusahaan bagi masyarakat. Istilah CSR dikenal pertama kali dikenalkan oleh Howard Bowen pada 1953. Menurutnya, CSR dikembangkan terkait dengan kewajiban para pengusaha (businessmen) untuk membuat kebijakan, keputusan dan tindakan yang bernilai bagi masyarakat. Frase businessmen terus dipakai sampai pertengahan 1960-an terkait dengan CSR. Dapat dikatakan Howard Bowen merupakan "father of corporate social responsibility" (Carroll, 1999: 270). Pemaknaan terhadap CSR terus berkembang dari hanya bersifat karitatif sampai dianggap sebagai bentuk investasi dan partisipasi perusahaan dalam pembangunan berkelanjutan. 
Corporate social responsibility (CSR) adalah sebuah hubungan antara sebuah korporasi dengan stakeholder-nya, juga masyarakat secara umum. (Aras dan Crowther, 2009: 23). Komisi Eropa menyebutkan bahwa CSR adalah konsep yang secara esensial merupakan keputusan sukarela perusahaan untuk berkontribusi bagi masyarakat yang lebih baik dan lingkungan yang bersih. (Hond, 2007: 11)

CSR didorong oleh sebuah kebutuhan memadukan kepedulian sosial dan lingkungan ke dalam keputusan dan operasional bisnis dan meningkatkan hubungan dengan pemangku kepentingan. Bagi perusahaan, CSR menjadi sebuah daya saing, khususnya pembentukan aset yang tidak terlihat, sebagai sebuah poin yang menarik dalam memasuki pasar. CSR pada prinsipnya disesuaikan dengan kemampuan finansial perusahaan (Keinert, 2008: 38-43)

CSR dari sudut pandang kepentingan perusahaan dapat dikelompokkan menjadi dua mazhab. Pertama, CSR dilaksanakan untuk meningkatkan keuntungan bisnis. Mazhab yang memahami bahwa CSR diperlukan karena menjadi salah satu faktor pendorong kemajuan perusahaan sehingga harus dilaksanakan secara sukarela, tanpa didasarkan pada dampak operasional perusahaan. Mazhab ini beranggapan bahwa CSR dilaksanakan hanya untuk shareholder saja. Kedua, mazhab yang beranggapan bahwa CSR dilaksanakan sebagai tanggung jawab dampak operasional perusahaan (Hond, 2007: 2-3). CSR yang dimaknai sebagai tanggung jawab terhadap dampak operasional perusahaan, terutama pada perusahaan yang terkait dengan sumber daya alam, lebih tepat karena akan menjamin program CSR dirasakan oleh masyarakat sekitar yang terkena dampak. Jika lebih berorientasi untuk meningkatkan profit, justru CSR akan cenderung diberikan kepada pihak yang memiliki posisi tawar, bukan kepada masyarakat yang lokal di sekitar tambang.

Aras dan Crowther (2004) mengungkapkan istilah CSR telah bergeser menjadi sustainability dan mereka mencatat bahwa ada empat aspek yang harus dicermati sebagai dasar analisis pentingnya sustainability yaitu (1) societal influence yang mencerminkan dampak sosial dari operasional perusahaan terhadap stakeholder, (2) environmental impact yang merupakan dampak kegiatan perusahaan terhadap lingkungan geofisik; (3) organisational culture yang menggambarkan hubungan antara perusahaan dengan internal stakeholder dan (4) finance yang menunjukkan kecukupan hasil dari resiko yang telah diambil (Aras dan Crowther, 2004: 25).

Pada hakikatnya pelaksanaan CSR didasari oleh adanya dampak operasional perusahaan terhadap masyarakat dan lingkungan alam. CSR merupakan salah satu bentuk peran perusahaan untuk memecahkan persoalan kemasyarakatan dan ekologi. CSR harus merefleksikan perbedaan-perbedaan masyarakat dan memperhatikan kebutuhan riil masyarakat setempat. Menurut Idemudia (2011: 1), dalam CSR masih terjadi tarik menarik antara prioritas lokal dengan harapan masyarakat global. Hal ini seperti yang ditulis Frynas (2009) bahwa CSR tidak dapat dipisahkan dari kenyataan politik, ekonomi dan masalah 
sosial lokal. Karena itu, bentuk dan prioritas CSR pada satu masyarakat dengan masyarakat lain bisa jadi berbeda.

Tekanan dari komunitas internasional yang mengharuskan perusahaan menjalankan program CSR sebagai salah satu syarat dalam interaksi bisnis mendorong program CSR menjadi bagian wajib perusahaan. Beberapa hasil penelitian yang terungkap dalam seminar "Persepsi dan Implementasi CSR di Indonesia" menunjukkan sektor bisnis dan masyarakat Indonesia umumnya memahami CSR masih sebatas donasi, filantropi dan upaya untuk memperoleh license to operate (Sandi, 2011). Itu mencerminkan bahwa program CSR pada umumnya tidak memiliki program yang didasari oleh kepentingan masyarakat, tetapi hanya untuk pemenuhan syarat interaksi bisnis internasional.

Hal itu tidak sejalan dengan filosofi tujuan CSR. CSR tidak lagi dipahami sebagai bentuk kedermawanan atau donasi perusahaan, tetapi merupakan bagian dari upaya menjaga keberlanjutan perusahaan. CSR sebagai filantrofi, karitatif, atau kedermawanan merupakan pemaknaan yang tidak tepat karena mengabaikan perkembangan dampak dari perusahaan (Aras dan Crowther, 2009: 4). Aras dan Crowther (2009: 23) menekankan bahwa aktivitas CSR didasarkan kepada tiga prinsip: sustainability, accountability dan transparency. Tiga prinsip tersebut mengharuskan program CSR berlandaskan akuntabilitas, keterbukaan dan keberlanjutan. Sustainabilit (keberlanjutan) berhubungan dengan kepentingan program CSR dan perusahaan itu sendiri. Sustainability mencerminkan bahwa CSR bermanfaat bagi perusahaan dan juga bagi semua stakeholder secara berkelanjutan.

Dalam satu istilah, akuntabilitas adalah kemampuan perusahaan untuk melaporkan atau mempertanggungjawabkan sesuatu kepada pihak tertentu. Akuntabilitas mewajibkan perusahaan untuk membuat laporan kepada stakeholder. Itu mencerminkan hubungan perusahaan dengan stakeholder. Akuntabilitas adalah bagian integral dari proses implementasi program CSR. (Henriques, 2004: 27). Di sisi lain, transparansi sering disebut berhubungan dengan akuntabilitas. Transparansi sangat penting untuk akuntabilitas karena berimplikasi terhadap tidak adanya suap dan korupsi (Henriques, 2004: 28).

Prinsip CSR tersebut menegaskan kembali keberpihakan perusahaan kepada good governance yang bebas korupsi. Penegakan transparansi dan akuntabilitas menjadi poin penting peran CSR dalam melawan praktik korupsi. Prinsip tersebut cukup untuk menjadi dasar bahwa CSR harus dilaksanakan dengan bersih dan bukan justru menjadi membuka peluang baru untuk korupsi.

Salah satu persoalan CSR adalah kecenderungan hanya melibatkan pihakpihak yang dianggap mempengaruhi perusahaan. Dengan kata lain, program CSR dilaksanakan untuk pihak yang dianggap dapat mempengaruhi atau menekan perusahaan. Riset menunjukkan bahwa CSR cenderung lebih mementingkan pihak-pihak yang memiliki kekuatan untuk mempengaruhi perusahaan (shareholder) dan sangat sedikit untuk masyarakat serta lingkungan (Aras dan Crowther, 2009: 23). Sekolah/madrasah yang tidak memiliki posisi tawar yang 
kuat tidak akan mendapat alokasi CSR meskipun pada dasarnya mereka adalah salah satu prioritas.

Program CSR lebih diarahkan untuk pihak-pihak yang dapat memberikan tekanan atau ancaman operasional perusahaan. Karena itu, salah satu pertimbangan pemberian dana CSR adalah kekuatan pihak tersebut dalam mempengaruhi jalannya perusahaan. Itulah yang dimaksud Pedersen dan Neergaard (2007: 81) bahwa salah satu motif eksternal CSR adalah respons terhadap tekanan kelompok masyarakat (NGO) atau individu. Hal itu dikritik Frynas (2009: 117-118) yang menyebutkan bahwa program community development perusahaan sering ditafsirkan sebagai membeli dukungan komunitas (buying the local communities support).

\section{Peluang CSR untuk Madrasah}

Pendidikan pada hakikatnya merupakan hak semua orang tanpa membedakan status sosial, ras dan agama. Hakikat keadilan 'equity' dalam pendidikan merupakan landasan utama dalam model ini. Berangkat dari filosofis ini, pendidikan siswa yang berada di daerah yang terkena dampak operasional tambang misalnya, harus diprioritaskan dibanding dengan siswa yang tidak tinggal di daerah terdampak. Hal itu terkait pula dengan filosofi CSR, bahwa pada hakikatnya, CSR dilaksanakan perusahaan sebagai bentuk tanggung jawab dampak operasional perusahaan terhadap masyarakat. Karena itu, program CSR perusahaan seharusnya tidak diberikan kepada seluruh masyarakat tanpa mempertimbangkan lokasi, di mana masyarakat tersebut berada. Dengan kata lain, program CSR seharusnya tidak dibagikan secara merata kepada seluruh wilayah kabupaten tanpa memperhatikan lokasi daerah apakah terdampak atau tidak. Di sini, program CSR berbeda dengan pajak yang dibayar oleh perusahaan tambang kepada daerah. Pajak atau royalti tersebut dapat dibagi secara merata ke seluruh kabupaten melalui berbagai bentuk pembangunan masyarakat, sedangkan dana CSR didistribusikan berdasarkan dampak (langsung) operasional tambang di daerah tersebut.

Dua hal yang idealnya menjadi fokus perhatian dalam pengelolaan CSR untuk madrasah adalah:

1. Penetapan Distribusi dan Alokasi untuk Madrasah

Metode penetapan alokasi dan distribusi dana CSR pada sebuah madrasah berdasarkan jumlah siswa yang berasal dari desa terdampak (ring 1 dan ring 2). Metode ini dapat mendorong kompetisi antar sekolah/madrasah untuk meningkatkan jumlah siswa dari desa terdampak dengan meningkatkan kualitas pendidikan di sekolah/madrasah tersebut. Model ini memprioritaskan siswasiswa desa dari desa terdampak yang selama ini tidak menjadi dasar dalam penetapan distribusi dan alokasi program CSR.

Distribusi dan alokasi pada sebuah madrasah idealnya didasarkan pada jumlah siswa dari desa terdampak yang terdaftar madrasah tersebut. Semakin banyak siswa dari desa terdampak, semakin besar pula dana CSR berbentuk block 
grant 'swakelola' yang dialokasikan di madrasah tersebut. Sedangkan unit cost dapat ditetapkan berdasarkan kemampuan pihak perusahaan. Dengan demikian, madrasah pun akan mendapat konpensasi yang diterima secara langsung dan berhak memutuskan sendiri untuk apa dana itu digunakan berdasarkan kebutuhan siswa agar sejalan dengan esensi manajemen berbasis madrasah. Dengan demikian, keterlibatan pihak ketiga dapat direduksi sehingga dana yang sampai langsung kepada proses pendidikan akan semakin besar, tanpa harus dibebani cost operasional pihak ketiga.

\section{Peran Madrasah dalam Perencanaan}

Perencanaan program CSR pendidikan idealnya dilakukan sepenuhnya oleh pihak madrasah. Dengan demikian, kebutuhan riil siswa akan dapat terakomodasi. Perspektif manajemen berbasis madrasah memberikan otonomi yang sangat luas bagi madrasah dalam proses perencanaan di madrasahnya. Kajian perencanaan pendidikan menegaskan bahwa perencanaan pendidikan dimulai dengan menentukan masalah (Banghart dan Albert, 1973). Bagaimana pun madrasah lebih memahami persoalan apa saja yang menghambat proses belajar di lembaga mereka. Oleh karena itu, perencanaan program CSR yang tidak melibatkan madrasah menjadi satu faktor yang dapat menghambat keberhasilan program CSR bidang pendidikan. Pada umumnya, keterlibatan madrasah dalam proses perencanaan program CSR sangat sedikit. Hal itu bertolak belakang dengan trend desentralisasi dalam school based management (SBM). Manajemen berbasis madrasah merupakan konsekuensi logis dari desentralisasi kewenangan ke tingkat sekolah. World Bank (2009) menyebutkan bahwa SBM akan meningkatkan outcome pendidikan. Pertama, SBM akan meningkatkan akuntabilitas kepala sekolah (termasuk madrasah) dan guru bagi siswa, orang tua dan guru. Mekanisme akuntabilitas yang menempatkan publik pada pusat pelayanan dan meningkatkan outcome dengan memfasilitasi partisipasi dalam pelayanannya. Kedua, SBM akan memberikan kesempatan pada penentu kebijakan lokal untuk memutuskan input yang tepat dan kebijakan yang sesuai realitas dan kebutuhan lokal. Dua temuan menunjukkan bahwa pelimpahan wewenang kepada sekolah/madrasah tersebut memberikan dampak terhadap hasil skor ujian. Jumlah keputusan yang dibuat di level madrasah akan berdampak positif terhadap hasil skor ujian (King and Ozler, 1998 dan Ozleer, 2001).

Proses perencanaan kegiatan yang tidak melibatkan madrasah akan mengabaikan kebutuhan dan realitas madrasah. Salah satu kritik terhadap CSR di beberapa negara adalah perhatian yang tidak sesuai dengan kenyataan politik, ekonomi dan masalah ekonomi yang dihadapi masyarakat. Di Nigeria misalnya, prioritas CSR adalah investasi sosial pada infrastruktur misalnya jalan, rumah sakit dan pusat pelayanan masyarakat. Itu tidak sesuai dengan masalah nyata masyarakat seperti lingkungan, korupsi, kurangnya akuntabilitas, kemunduran industri dan pertanian yang hanya sedikit mendapat perhatian (Idemudia, 2011). 
Perencanaan merupakan fase yang sangat menentukan dalam pembiayaan pendidikan. John dan Morphet (1975) menyebutkan bahwa perencanaan merupakan instrumen utama dalam pembangunan yang efektif termasuk penyediaan dukungan dana. Dia mengakui bahwa perencanaan yang efektif merupakan sesuatu yang tidak mungkin, tetapi paling tidak perencanaan itu merupakan komitmen dan didukung oleh pemerintah di semua level dana yang cukup, dan sumber daya yang digunakan secara efektif.

3. Transparansi dalam Program CSR Pendidikan

Program CSR sangat rentan terhadap praktik korupsi. Salah satu penyebabnya adalah tidak adanya undang-undang tentang tindak pidana korupsi di lembaga swasta. UU Nomor 31 Tahun 1999 tentang Pemberantasan Tindak Pidana Korupsi tidak secara jelas mengatur ancaman korupsi di kalangan swasta. Dengan kata lain, peraturan perundang-undangan antikorupsi di Indonesia tidak secara spesifik dan khusus menempatkan sektor swasta sebagai subjek hukum yang dapat dipidana. Penegak hukum sangat sulit untuk mengusut pidana korupsi di lembaga swasta yang tidak terkait dengan keuangan negara. Jika ada perundang-undangan yang tegas dan jelas, diharapkan peluang korupsi dapat di reduksi. Singapura misalnya, pemberantasan korupsi dilaksanakan dengan mengurangi peluang untuk korupsi dan meningkatkan hukuman bagi koruptor (Quah, 1999).

Upaya pencegahan korupsi di sektor swasta telah mendapat perhatian serius negara-negara di dunia. Dalam Article 12 United Nations Convention Againts Corruption (2003) disebutkan bahwa negara harus mencegah tindakan korupsi di sektor swasta, kemudian pada article 21 juga disebutkan tentang penyuapan di sektor swasta yang harus dianggap sebagai tindakan kriminal. Lebih detil pada article 12 poin 2 konvensi tersebut juga menyebutkan kewajiban negara-negara peserta konvensi untuk melakukan pencegahan korupsi yang melibatkan sektor swasta, meliputi antara lain:

a. Meningkatkan kerjasama di antara badan-badan penegak hukum dan badan-badan hukum perdata yang bersangkutan;

b. Meningkatkan pengembangan standar-standar dan prosedur-prosedur yang dirancang untuk melindungi integritas badan-badan hukum swasta yang bersangkutan;

c. Meningkatkan transparansi di antara badan-badan hukum swasta;

d. Mencegah penyalahgunaan prosedur-prosedur yang mengatur badan hukum perdata;

e. Mencegah benturan kepentingan dengan menerapkan pembatasanpembatasan untuk jangka waktu yang wajar bagi kegiatan-kegiatan profesional mantan pejabat-pejabat publik;

f. Memastikan bahwa perusahaan-perusahaan swasta, dengan memperhitungkan struktur dan besarnya mereka, memiliki 
pengawasan audit internal membantu mencegah dan melacak perbuatan-perbuatan korupsi.

Korupsi sektor swasta juga mendapat perhatian serius negara-negara di Afrika. African Union Convention on Preventing and Combating Corruption article 11 menegaskan bahwa setiap negara harus mengambil tindakan-tindakan tegas dalam rangka mencegah dan memberantas korupsi yang berkaitan dengan agenagen di sektor swasta; membuat mekanisme untuk meningkatkan partisipasi sektor swasta untuk memerangi persaingan curang; menghormati prosedur tender dan hak atas kekayaan intelektual; serta mengambil tindakan-tindakan yang diperlukan dalam rangka mencegah perusahaan-perusahaan dari pemberian suap untuk memenangi suatu tender di antara para pelaku bisnis.

Peran sektor swasta dalam pemberantasan korupsi dalam segala bentuk termasuk pemerasan dan penyuapan ditegaskan pula pada prinsip kesepuluh The UN Global Compac's. Sundaram (2009: xxi) menyebutkan keterlibatan aktif komunitas perusahaan adalah salah satu strategi untuk melawan korupsi. Keterlibatan perusahaan tersebut tercermin pada pengaturan CSR yang mendorong perusahaan untuk mengintegrasikan tindakan anti korupsi sebagai cara untuk memperbaiki reputasi perusahaan. Etika bisnis dan integritas tersebut merupakan bukti praktik dan manajemen yang baik.

Transparansi sangat penting dalam pengelolaan dana CSR pendidikan. Bukti empiris dari keuntungan transparansi adalah pendidikan di Uganda (Ackerman, 2006: 82). Tingkat korupsi di negara tersebut sangat tinggi sehingga setiap \$1 dari dana pemerintah untuk pendidikan hanya 20 sen yang sampai ke sekolah dasar lokal yang menjadi target. Perubahan dengan meningkatkan publikasi (sehingga orang tua sadar tentang alokasi dana) dan monitoring meninggikan dana yang sampai ke sekolah tersebut menjadi $\$ 80$ sen. Selain sebagai bentuk akuntabilitas, penelitian tersebut membuktikan bahwa transparansi dalam pembiayaan pendidikan akan meningkatkan input langsung terhadap proses pendidikan yang akan berimplikasi pula pada kualitas hasil pendidikan tersebut.

Dalam perspektif baru, akuntabilitas membawa dua konotasi: answerability dan enforcement. Answerability adalah kewajiban dari pengelola untuk menginformasikan publik dan menjelaskan atau menjustifikasi apa rencana yang sedang dikerjakan atau yang telah dikerjakan. Answerability memiliki dua elemen yaitu informasi dan justifikasi. Tanpa informasi yang terbuka dalam kegiatannya, organisasi atau pemerintah sangat sulit untuk akuntabel. Enforcement merupakan kemampuan organisasi untuk memberikan sanksi terhadap yang lalai dalam melakukan tugas dan memberikan penghargaan kepada mereka yang telah bekerja dengan baik (Ma and Hou, 2009). Pada sekolah, Adam dan Kirts (1999: 464) juga menyebutkan bahwa akuntabilitas tidak hanya menyangkut peningkatan prestasi akademik siswa tetapi menyangkut pembinaan hubungan dengan masyarakat yang dapat menghasilkan dukungan masyarakat terhadap 
sekolah. Akuntabilitas menjadi faktor pendorong kepercayaan publik terhadap lembaga pendidikan.

\section{SIMPULAN}

Pada daerah-daerah operasional perusahaan yang terkena langsung dampak perusahaan, program CSR pendidikan menjadi sumber pembiayaan pendidikan yang sangat potensial. Namun, realisasi program CSR belum dirasakan nyata oleh pihak madrasah. Dalam hal penetapan distribusi dan alokasi dana bantuan pun, pihak madrasah tidak diberi kewenangan untuk memutuskan sendiri perihal penggunaan dana yang biasanya didasarkan pada kebutuhan siswa agar sejalan dengan esensi manajemen berbasis madrasah. Artinya, perusahaan masih terlalu dominan dalam menentukan arah penggunaannya. Perencanaan program CSR pun sering tidak melibatkan madrasah. Mestinya, ada sinergi antara program CSR dengan program madrasah guna menghasilkan madrasah yang berkualitas dan sesuai dengan kebutuhan masyarakat. Riset-riset terdahulu menunjukkan bahwa CSR cenderung lebih mementingkan pihak-pihak yang memiliki kekuatan untuk mempengaruhi perusahaan (shareholder) dan sangat sedikit memberikan manfaat bagi masyarakat serta lingkungan. Madrasah, sebagai salah satu lembaga pendidikan Islam di Indonesia kurang memiliki daya tawar yang kuat sehingga sering tidak mendapatkan alokasi pendanaan CSR. Madrasah dapat berpeluang mendapatkan dana CSR, dengan memperhatikan beberapa hal di antaranya; 1) lokasi madrasah terkena dampak langsung dari perusahaan, 2) melibatkan diri dalam program CSR dan 3) adanya akuntabilitas/jaminan transparansi pengelolaan keuangan. Di pihak perusahaan, program CSR idealnya dijadikan sebagai trade mark, sebagai wujud tanggung jawab sosial perusahaan terhadap kepentingan masyarakat, khususnya pendidikan madrasah yang rata-rata milik masyarakat namun minim dari segi pendanaan.

\section{DAFTAR PUSTAKA}

Ackerman, Susan Rose. 2009. "The Challenge of Poor Governance and Corruption" Dalam Bjørn Lomborg (Ed) How to Spend $\$ 50$ Billion to Make the World A Better Place, Cambridge: Cambridge University Press.

Aras, Güler and David Crowther. 2009. "Corporate Governance and Corporate Social Responsibility in Context", dalam Güler Aras and David Crowther, (Ed), Global Perspectives on Corporate Governance and CSR. Farnham Surrey: Gower Publishing Limited.

Azheri, Busyra. 2011. Corporate Social Responsibility: Dari Voluntary Menjadi Mandatory, Jakarta: Rajawali Pers.

Carroll, Archie B. 1999. "Corporate Social Responsibility" dalam Business and Society; Sep 1999; 38, 3; ProQuest Sociology.

Elkington, John. 1997. Cannibals with Forks: the TBL of 21st century business Oxford: Capstone. 
Frynas, Jedrzej George. 2009. Beyond Corporate Social Responsibility: Oil Multinationals and Social, Challenges. New York: Cambridge University Press.

Greenwald, R., Hedges, L., \& Laine, R. 1996. "The effect of school resources on student achievement", Review of Educational Research, 66(3), 361-396. (Online) tersedia http://search.proquest.com/docview/214118755/fulltext/1334CD2A60365 A6F3F3/3? accountid=35150, diunduh tanggal 21 September 2011.

Holmlund, Helena, et. all. 2010. Does Money Matter for Schools?, Economics of education review, 29(6) (online) tersedia http:/ / www.economistsonline.org/scholar?partnerId=lse-acuk\&scholarId=sandra.monally, diunduh tanggal 15 September 2011.

Hond, Frank, Etall. 2007. Introduction to Managing Corporate Social Responsibility in Action: Talking, Doing and Measuring. Hampshire England: Ashgate Publishing Limited.

Idemudia, Uwafiokun. 2011. "Corporate Social Responsibility and Developing Countries: Moving the Critical CSR Research Agenda in Africa Forward", Progress in Development Studies 11, 1 (2011) pp. 1-18.

John, R, L., and Morphet, Edgar, L. 1975. The Economic and Financing of Education. New Jersey: Prentice Hall, Inc. Englewood Clifs.

John, R. L., Morphet, Edgar, L dan Kern, Alexander. 1983. The Economics and Financing of Education, 4th Edition, New Jersey: Prentice Hall, Inc. Englewood Clifs.

Keinert, Christina. 2008. "Corporate Social Responsibility as an International Strategy", dalam Cristina Keinert (ed), Corporate Social Responsibility as an International Strategy, New York : Springer.

Ma, Jun, Hou, Yilin. 2009. "Budgeting for Accountability: A Comparative Study of Budget Reforms in the United States during the Progressive Era and in Contemporary China", Public Administration Review, suppl. Special Issue on Comparative Chinese/American Public .., Dec 2009, : 53-59. (Online) tersedia http:/ / search.proquest.com/docview/852999736/fulltext/1329F204FED7B E2554E/2?accountid=35150 diunduh tanggal 26 Januari 2011.

Ma, Jun, Hou, Yilin. 2009. "Budgeting for Accountability: A Comparative Study of Budget Reforms in the United States during the Progressive Era and in Contemporary China", Public Administration Review, suppl. Special Issue on Comparative Chinese/American Public .., Dec 2009, : 53-59. (Online) tersedia http://search.proquest.com/docview/852999736/fulltext/1329F204FED7B E2554E/2?accountid $=35150$ diunduh tanggal 26 Januari 2011.

Molly, Sherlock. 2011. "The Effects of Financial Resources on Test Pass Rates: Evidence from Vermont's Equal Education Opportunity Act”, Public Finance Review May 2011 vol. 39 no.3 p.331-364 (Online) tersedia dalam http://pfr.sagepub.com/content/39/3/331.full.pdf+html diunduh tanggal http:/ / www.tandfonline.com/action/doSearch?action $=$ runSearch\&type $=a d v$ anced $\&$ result $=$ true\&prevSearch $=\% 2$ Bauthorsfield $\% 3 \mathrm{~A}($ Murillo $\% 2 \mathrm{C}+\mathrm{F} .+$ Javi er) di unduh tanggal 15 September 2011. 
Murphy, Mary Kay. 1989. "Corporations and Foundation”, dalam James L. Fisher dan Gary H. Quehl (Ed). The President and Fund Raising. New York: Macmillan Pub. Company.

Nishimuko, Mikako. 2007. "Problems behind Education for All (EFA): The case of Sierra Leone" Educate The Journal of Doctoral Research in Education Volume 7 Number 2 2007, London: Intitute of Education University of London (Online) tersedia http://www.educatejournal.org /index.php? journal =educate\&page $=$ article\&op $=$ view\&path $]=115 \&$ path $]=141 . \quad$ Diunduh tanggal 5 April 2007.

Normore, A. H. and L. Ilon. 2006. "Cost-effective school inputs - Is class size reduction the best educational expenditure for Florida?" Educational Policy Vol 20.

Pedersen, Esben Rahbek dan Neergaard, Peter. 2007. “The Bottom Line of CSR: A Different View", dalam Frank den Hond, etall (Ed), Managing Corporate Social Responsibility in Action, Burlington: Ashgate Publishing Company.

Quah, Jon. ST. 1999. "Corruption in Asian Countries: Can it be Minimized" Public Administration Review 59, 6, Nov/Dec 1999, 483-494.

Ross, John, A. Khaled Barkaoui and Garth Scott. 2007. "Evaluations That Consider the Cost of Educational Programs: The Contribution ofHigh-Quality Studies", American Journal of Evaluation. Volume 28, (online), tersedia http://aje.sagepub.com/cgi/reprint/28/4/477, diunduh tanggal 2 April 2009.

Sundaram. Jomo Kwame. 2009. "The Role of the Private Sector in Fighting Corruption: Essential for Meeting Local and Global Governance Challenges", dalam Global Corruption Report 2009: Corruption and the Private Sector. New York: Cambridge University Press.

United Nations Convention Againts Corruption, 2003.

Wenglinsky, H. 1997. "How Money Matters: The Effect of School District Spending on Academic Achievement", Sociology of Education, 70(3), 221-237. (Online) tersedia http://search.proquest.com/docview/, diunduh tanggal 11 Juli 2011. 